\title{
Crystal Structure and Third Order Nonlinear Optical Studies on 2-phenylbenzimidazolium-p-toulenesulphonate
}

\section{C.SUDHAKAR ${ }^{1,2}$, M.SARAVANABHAVAN ${ }^{3}$, M.SEKAR $^{2 \star}$, B.BABU ${ }^{4}$ and J.CHANDRASEKARAN ${ }^{4}$}

${ }^{1}$ Research and Development Centre, Bharathiar University, Coimbatore - 641 046, Tamil Nadu, India. ${ }^{2}$ Chikkaiah Naicker College,Erode-638004,Tamilnadu, India

${ }^{3}$ Department of Chemistry, Dr. N.G.P. Institute of Technology, Coimbatore -641048, Tamil Nadu, India. ${ }^{4}$ Post-Graduate and Research Department of Chemistry, Sri Ramakrishna Mission Vidyalaya College of Arts and Science, Coimbatore - 641 020, Tamil Nadu, India.

${ }^{5}$ Post-Graduate and Research Department of Physics, Sri Ramakrishna Mission Vidyalaya College of Arts and Science, Coimbatore - 641 020, Tamil Nadu, India.

Corresponding author E-mail: drmsbavan@gmail.com

http://dx.doi.org/10.13005/ojc/340116

(Received: June 01, 2017; Accepted: August 25, 2017)

\begin{abstract}
A new third order nonlinear optical single crystal of 2-phenylbenzimidazolium-ptoulenesulphonate (PBITS) was grown by the solvent evaporation technique using methanol as a solvent. The single crystal XRD analysis reveals that crystals belong to the triclinic system. An NMR and FTIR study confirms the formation and vibrational analysis present in the compound. UV-Vis absorption studies were also carried out for the crystal. Nonlinear refractive index $\left(n_{2}\right)$, absorption coefficient $(\beta)$ and third order nonlinear optical susceptibility $\left(\left(\chi^{(3)}\right)\right)$ of the crystals were evaluated by Z-Scan studies.
\end{abstract}

Keyword: Crystal, 2-phenylbenzimidazolium-p-toulenesulphonate (PBITS), Crystal XRD, NMR and FTIR study.

\section{INTRODUCTION}

A fascinating new field of research termed "nonlinear" optics was introduced to the scientific and engineering community after the invention of laser. Nonlinear optics has arisen as one of the most attractive fields of current research in view of its vital applications in areas of optical switching, optical data storage for the developing technologies in telecommunications, frequency mixing, optical parametric oscillation, optical bi-stability, optical logic gates, laser radiation protection, optical image processing, under water communication, biomedical and signal processing analysis etc ${ }^{1-5}$.

This is an $\mathbf{C}$ Open Access article licensed under a Creative Commons Attribution-NonCommercial-ShareAlike 4.0 International License (https://creativecommons.org/licenses/by-nc-sa/4.0/ ), which permits unrestricted NonCommercial use, distribution and reproduction in any medium, provided the original work is properly cited. 
Organic NLO single crystals are very efficient for $\mathrm{THz}$ generation and high signal to noise ratios detection due to their large nonlinear optical susceptibilities and ultrafast response times ${ }^{6,7}$. It has been understood that the second-order and third-order molecular nonlinearity can be enhanced by large delocalized $\pi$-electron systems with strong donor and acceptor groups ${ }^{8-10}$. Based on these specifies in the present investigation donor-acceptor based crystals of 2-phenylbenzimidazolium-ptoulenesulphonate has been grown by the slow evaporation technique andits structural, optical, and third order nonlinear optical properties were discussed in detail.

\section{EXPERIMENTAL}

\section{Material synthesis and growth of pbitssingle crystal}

Equimolar ratio of $p$-toluenesulphonic acid in methanol and 2-phenylbenzimidazole in methanol were prepared at room temperature, mixed and stirred well for about $3 \mathrm{~h}$ to get clear solution. This solution was filtered using Whatmann 41 filter paper and kept aside unperturbed in a dust-free room for the growth of single crystals. Well defined, transparent crystals were collected at the end of $6^{\text {th }}$ day. The collected crystals were recrystallized using dry methanol to get good quality crystals. The reaction scheme and the chemical structure were illustrated.

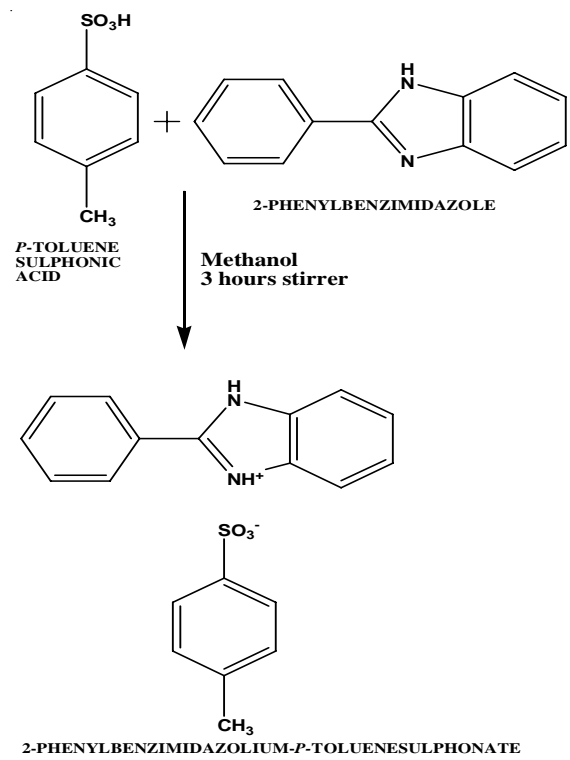

Scheme 1. Synthesis of 2-phenylbenzimidazoliump-toulenesulphonate

\section{Materials and instrumentation}

All the chemicals were purchased from Sigma-Aldrich in the highest purity available. Solvents were purified and dried according to the standard procedure. Single crystal X-ray diffraction data of PBITS compound was collected at room temperature on a Bruker Diffractometer equipped with a fine focused sealed tube. The unit cell parameters were determined and the data collections of PBITSwas performed using a graphite-mono chromate Mo K $\alpha(\lambda=0.71073 \AA)$ radiation by $\varphi$ and $\omega$ scans. The structure of the compound was solved by direct method using SHELXS-97, which revealed the position of all nonhydrogen atoms, and was refined by full-matrix least squares on $\mathrm{F}^{2}$ (SHELXL-97) ${ }^{11}$. All non-hydrogen atoms were refined anisotropically, while the hydrogen atoms were placed in calculated positions and refined as riding atoms. The electronic absorption spectrum was measured in methanol using SHIMADZU 1601 UV-Vis spectrophotometer in the range of $200-600 \mathrm{~nm}$. In order to confirm the functional groups of the crystal was subjected to FT-IR spectral analysis by Perkin Elmer FT-IR 8000 spectrophotometer in the range of $4000-400 \mathrm{~cm}^{-1}$ using the $\mathrm{KBr}$ pellets method. To confirm the molecular structure of the compound the ${ }^{1} \mathrm{H}$ and ${ }^{13} \mathrm{C}$ NMR spectra were recorded employing a Bruker AV III $400 \mathrm{MHz}$ spectrometerin deuterated dimethyl sulfoxide as solvent using TMS as an internal standard. The nonlinear optical measurements were carried out by using single beam Z-scan technique with a $\mathrm{He}-\mathrm{Ne}$ laser operated at a repetition rate of $1 \mathrm{kHz}$ and at the wavelength of $632 \mathrm{~nm}$.

\section{RESULTS AND DISCUSSIONS}

\section{Single crystal XRD analysis}

From X-ray diffraction studies, it is known that the crystal belongs to the triclinic system with the space group of $\mathrm{P}-1$ and the lattice parameters are $\mathrm{a}=8.2912(5) \AA \mathrm{A}, \mathrm{b}=9.7197(6) \AA \AA \mathrm{c}, \mathrm{c}=11.4293(9) \AA$ $=82.311(4)^{\circ}, \beta=89.626(3)^{\circ}, \gamma=77.915(3)^{\circ}$. The crystal data and details of the data collection and the structure refinement are given in Table. 1. The bond length and bond angles of PBITS crystal are given in Table 2 and 3 respectively. Fig. 1 shows the ORTEP view of the molecule drawn at $50 \%$ probability thermal displacement ellipsoids with the atom numbering scheme. The packing arrangement 
of the molecule viewed down $a, b$ and $c$ axis are shown in Fig. 1.a, b, and c respectively. From molecular structure of PBITS, we could see that there is an intermolecular hydrogen bonding between $\mathrm{N}-\mathrm{H}$ group of 2-phenylbenz imidazoliniumcation and $P$-toluenesulphonate anion. The $\mathrm{N}$-atom of the 2-phenyl benzimdazole cation forms $\mathrm{N}-\mathrm{H}$........ hydrogen bonds with the $\mathrm{O}$ atom of the 2-phenyl sulphonate anion. In the title compound the $\mathrm{C}=\mathrm{NH}$ group of the 2-phenylbenzimidazole residue is engaged in the strong hydrogen bonding with the $P$-toluenesulphonatesulphonate anion. The selected bond distance and angles are shown in Table4 respectively. The molecule is stabilized by $\mathrm{C}-\mathrm{H} \ldots \ldots . \mathrm{O}$ bifurcated hydrogen bonds. All non-hydrogen atoms were refined anisotropically and the hydrogen atoms were placed in geometric positions and refined as riding atoms except for those bound to oxygen and nitrogen, which were freely refined.
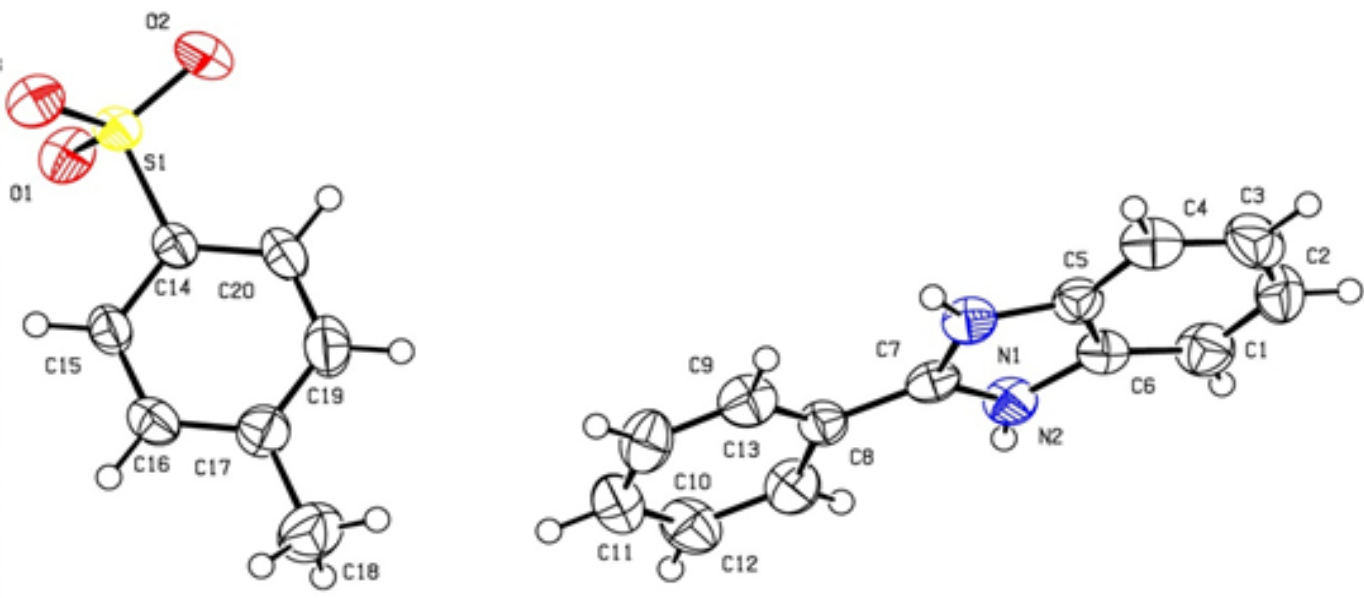

Fig. 1. ORTEP diagram of PBITS

\section{NMR spectral analysis}

The ${ }^{1} \mathrm{H}$ NMR spectrum of the PBITS single crystal was recorded employing a Brucker $400 \mathrm{MHz}$ spectrometer using TMS as the internal reference standard. The ${ }^{1} \mathrm{H}$ NMR spectrum of the PBITS is depicted in Fig. 2.The singlet peak observed at $\delta$ 2.298 has been assigned to three protons of the methyl group in the 2-phenylbenzoimidazolium $p$-toluenesulphonate. The doublet peak centred at $\delta 7.146(\mathrm{~J}=8 \mathrm{~Hz})$ is due to the $\mathrm{C}_{19}$ and $\mathrm{C}_{16}$ protons of the same kind in aromatic ring of 2-phenylbenzoimidazolium- $p$-toluenesulphonate. Another doublet peak centred at $\delta 8.226(\mathrm{~J}=6.8 \mathrm{~Hz})$ is due to the $\mathrm{C}_{15}$ and $\mathrm{C}_{20}$ protons of the same kind in aromatic ring of 2 phenylbenzoimidazolium- $p$ toluenesulphonate. The multiplet peak centred at $\delta$ 7.901-7.572 is due to the $\mathrm{C}_{1}, \mathrm{C}_{2}, \mathrm{C}_{3}, \mathrm{C}_{4}, \mathrm{C}_{9}, \mathrm{C}_{10}, \mathrm{C}_{11}$, $C_{12}$ and $C_{13}$ protons of the same kind of the aromatic ring of 2-phenylbenzoimidazolium- $p$ toluenesulphonate. The $\mathrm{NH}$ proton appeared as singlet at $\delta 5.4$.
The ${ }^{13} \mathrm{C}$ NMR spectrum of the PBITS single crystal was recorded employing a Brucker $400 \mathrm{MHz}$ spectrometer using TMS as the internal reference standard. The ${ }^{13} \mathrm{C}$ NMR spectrum of the PBITS is depicted in Fig. 3. In the downfield carbon signal at $\delta 154.25$ is correspond to the $C_{7}$ carbon of 2-phenylbenzimidazole moiety. The carbon signal at $\delta 150.22$ is belongs to the $C_{14}$ carbon of $p$-toluenesulphonicacid moiety. The carbon signal at $\delta 143.41$ is correspond to the $C_{5}$ carbon of p-toluenesulphonicacid moiety. The carbon signal at $\delta 138.63$ is belongs to the $C_{4}$ carbon of 2-phenylbenzimidazole moiety. The sharp and intense signal at $\delta 137.06$ is due to the $C_{15}$ and $C_{20}$ carbons of the same kind in the $\mathrm{p}$-toluenesulphonicacid moiety. The carbon signal at $\delta 134.94$ is correspond to the $\mathrm{C}_{8}$ and $\mathrm{C}_{11}$ carbons of 2 phenylbenzimidazole moiety. The sharp and intense signal at $\delta 133.20$ is due to the $\mathrm{C}_{9}$ and $\mathrm{C}_{13}$ carbons of the same kind in the2-phenylbenzimidazole moiety. The carbon signal at $\delta 131.28$ is belongs to the $C_{10}$ and $C_{12}$ 
carbon of 2-phenylbenzimidazole moiety. The carbon signal at $\delta 130.74$ is correspond to the $C_{16}$ and $\mathrm{C}_{19}$ carbon of 2-phenylbenzimidazole moiety. The sharp and intense signal at $\delta 128.31$ is due to the $\mathrm{C}_{2}$ and $\mathrm{C}_{3}$ carbons of the same kind in the $\mathrm{p}$ - toluenesulphonicacid moiety. The sharp and intense signal at $\delta 119.36$ is due to the $C_{17}$ carbon of the same kind in the 2-phenylbenzimidazole moiety. The carbon signal at $\delta 26.02$ is correspond to the methyl carbon of 2-phenylbenzimidazole moiety.

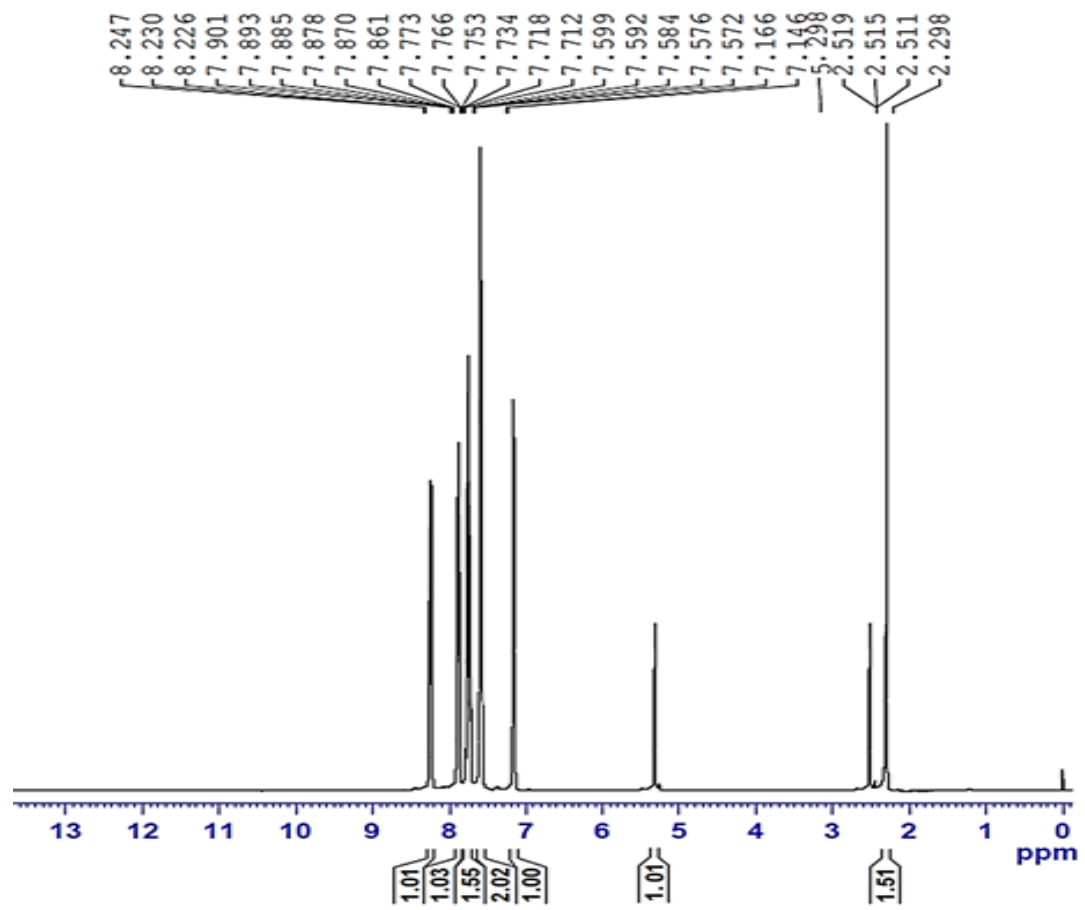

Fig. 2. ${ }^{1} \mathrm{H}$ NMR spectrum of PBITS

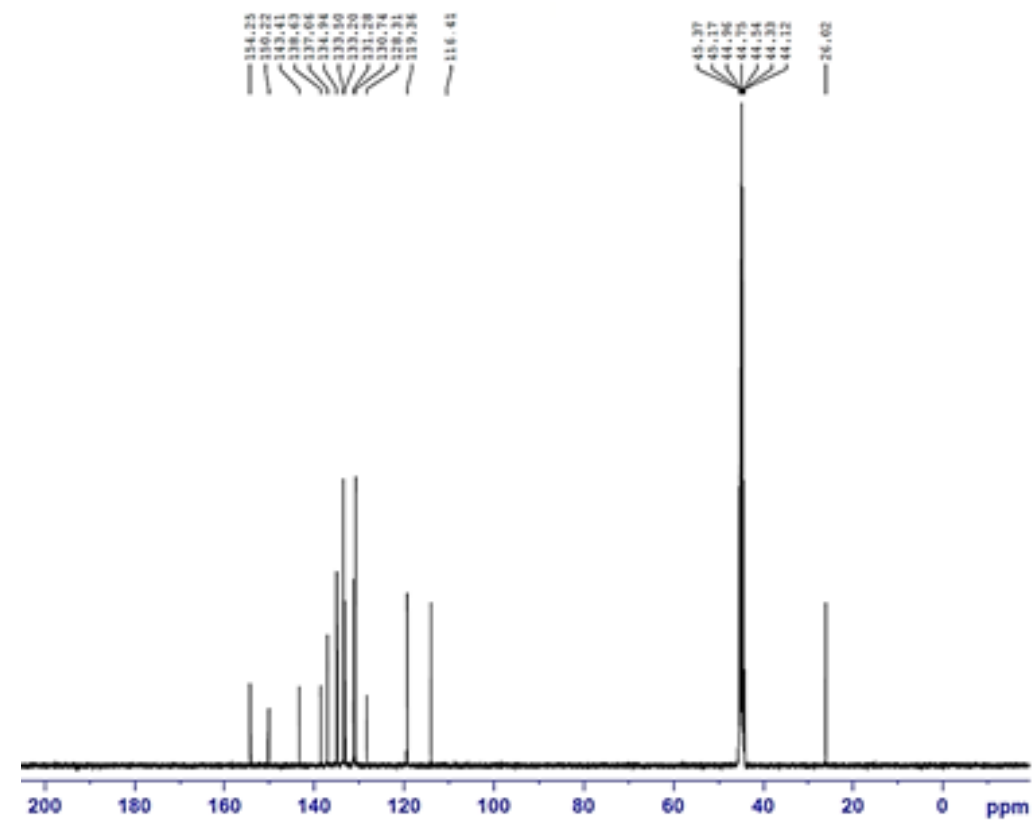

Fig. $3 .{ }^{13} \mathrm{C}$ NMR spectrum ofPBITS 


\section{FT-IR SPECTRAL STUDIES}

The FT-IR spectrum of PBITS crystal was recorded employing a Perkin Elmer FT-IR spectrometer using $\mathrm{KBr}$ pellet technique in the range $4000-400 \mathrm{~cm}^{-1}$ and the FT-IR spectrum of PBITScrystal is depicted in Fig. 4. The recorded FTIR spectrum was analyzed to ascertain the functional groups presented in the compound. The formation of the PBITSduring the reaction between $p$ toluenesulphonicacid and 2-phenylbenzimidazole strongly evident by the presence of the main characteristic infrared band present in the crystal. The formation of PBITS is evident by the presence of most prominent group in PBITScrystal such as $\mathrm{N}-\mathrm{H}, \mathrm{C}-\mathrm{H}, \mathrm{C}=\mathrm{N}, \mathrm{C}-\mathrm{N}$ and $\mathrm{SO}_{2}$ groups. The band observed at $3336 \mathrm{~cm}^{-1}$ is due to the $\mathrm{N}-\mathrm{H}$ symmetric stretching vibration. The aromatic $\mathrm{C}-\mathrm{H}$ stretching vibration is observed at $3062 \mathrm{~cm}^{-1}, 2930 \mathrm{~cm}^{-1}$ and $2853 \mathrm{~cm}^{-1}$. The band observed at $1634 \mathrm{~cm}^{-1}$ is indicate the presence of $\mathrm{C}=\mathrm{N}$ group in the PBITS molecule. The aromatic $\mathrm{C}-\mathrm{H}$ bending vibration is observed at $1457 \mathrm{~cm}^{-1}$. The band $1396 \mathrm{~cm}^{-1}$ indicates the presence of $\mathrm{C}-\mathrm{N}$ stretching vibration in the molecule. The sharp band observed at1166 $\mathrm{cm}^{-1}$ indicates the presence of aromatic $\mathrm{SO}_{2}$ symmetric stretching vibration.

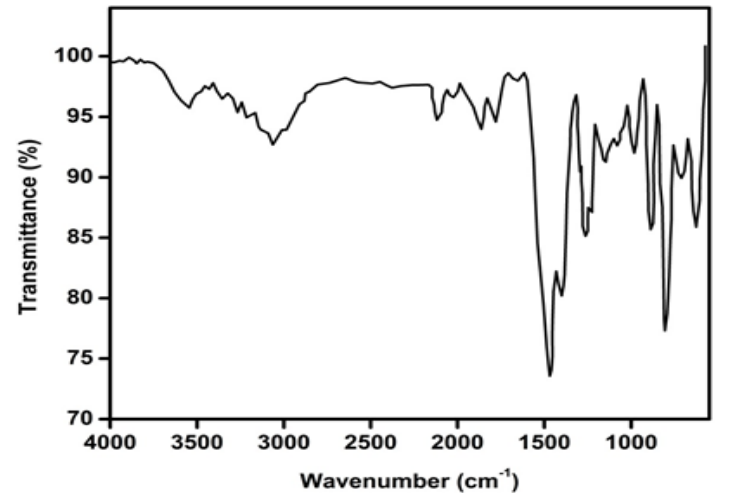

Fig. 4. FT-IR spectrum of PBITS

Electronic absorption spectroscopic studies

The UV-Visible absorption spectrum of PBITS crystal was recorded employing a systronics make double beam spectrophotometer 2202 in a range from 200 to $600 \mathrm{~nm}$ using DMSO as solvent and the spectrum shown in Fig. 5. From the spectrum, it is observed that the compound exhibits two characteristics absorption bands. The bands at about 296.0 and $329.6 \mathrm{~nm}$ are assigned to $\pi \rightarrow \pi *$ transition of the title compound. Also the absence of absorption in the region between 330 $\mathrm{nm}$ to 600 $\mathrm{nm}$ makes the crystal suitable for optical applications ${ }^{7,12}$.

Table. 1: Crystal data and structure refinement for PBITS

\begin{tabular}{|c|c|}
\hline Empirical formula & $\mathrm{C}_{20} \mathrm{H}_{18} \mathrm{~N}_{2} \mathrm{O}_{3} \mathrm{~S}$ \\
\hline Formula weight & 366.42 \\
\hline Temperature & 296(2) K \\
\hline Wavelength & $0.71073 \AA$ \\
\hline Crystal system, space group & Triclinic, $\mathrm{P}-1$ \\
\hline Unit cell dimensions & $\begin{array}{c}a=8.2912(5) \AA, \text { alpha }=82.311(4) \mathrm{deg} \\
\mathrm{b}=9.7197(6) \AA, \text { beta }=89.626(3) \mathrm{deg} \\
\mathrm{c}=11.4293(9) \AA, \text { gamma }=77.915(3) \mathrm{deg}\end{array}$ \\
\hline Volume & $892.33(10) A^{3}$ \\
\hline Z, Calculated density & $2,1.364 \mathrm{Mg} / \mathrm{m}^{3}$ \\
\hline Absorption coefficient & $0.204 \mathrm{~mm}^{-1}$ \\
\hline$F(000)$ & 384 \\
\hline Crystal size & $0.35 \times 0.30 \times 0.25 \mathrm{~mm}$ \\
\hline Theta range for data collection & 1.80 to $28.36 \mathrm{deg}$. \\
\hline Limiting indices & $-11<=\mathrm{h}<=8, \quad-12<=\mathrm{k}<=11,-15<=\mathrm{k}<=15$ \\
\hline Reflections collected / unique & $6971 / 4272[\mathrm{R}(\mathrm{int})=0.0167]$ \\
\hline Completeness to theta $=28.36$ & $95.90 \%$ \\
\hline Absorption correction & Semi-empirical from equivalents \\
\hline Max. and min. Transmission & 0.9508 and 0.9320 \\
\hline Refinement method & Full-matrix least-squares on $\mathrm{F}^{2}$ \\
\hline Data / restraints / parameters & 4272 / 0 / 236 \\
\hline Goodness-of-fit on $\mathrm{F}^{\wedge} 2$ & 1.071 \\
\hline Final $R$ indices $[\mathrm{I}>2$ sigma( $(\mathrm{I})]$ & $\mathrm{R} 1=0.0543, \mathrm{wR} 2=0.1481$ \\
\hline $\mathrm{R}$ indices (all data) & $\mathrm{R} 1=0.0670, \mathrm{wR} 2=0.1642$ \\
\hline Largest diff. peak and hole & 0.643 and -0.471 e. $A^{-3}$ \\
\hline
\end{tabular}


Table. 2: Bond lengths [Å] forPBITS

\begin{tabular}{|c|c|}
\hline $\mathrm{S}(1)-\mathrm{O}(2)$ & $1.4383(17)$ \\
\hline $\mathrm{S}(1)-\mathrm{O}(3)$ & $1.4562(15)$ \\
\hline $\mathrm{S}(1)-\mathrm{O}(1)$ & $1.4584(16)$ \\
\hline$S(1)-C(14)$ & $1.772(2)$ \\
\hline $\mathrm{N}(1)-\mathrm{C}(7)$ & $1.325(3)$ \\
\hline$N(1)-C(5)$ & $1.397(3)$ \\
\hline $\mathrm{N}(1)-\mathrm{H}(1 \mathrm{~N} 1)$ & 0.86 \\
\hline$N(2)-C(7)$ & $1.328(3)$ \\
\hline$N(2)-C(6)$ & $1.389(3)$ \\
\hline $\mathrm{N}(2)-\mathrm{H}(2 \mathrm{~N} 2)$ & 0.86 \\
\hline$C(3)-C(4)$ & $1.383(4)$ \\
\hline$C(3)-C(2)$ & $1.410(4)$ \\
\hline $\mathrm{C}(3)-\mathrm{H}(3)$ & 0.93 \\
\hline$C(4)-C(5)$ & $1.380(3)$ \\
\hline $\mathrm{C}(4)-\mathrm{H}(4)$ & 0.93 \\
\hline$C(5)-C(6)$ & $1.378(3)$ \\
\hline$C(7)-C(8)$ & $1.475(3)$ \\
\hline $\mathrm{C}(8)-\mathrm{C}(9)$ & $1.398(3)$ \\
\hline$C(8)-C(13)$ & $1.399(3)$ \\
\hline$C(9)-C(10)$ & $1.368(4)$ \\
\hline $\mathrm{C}(9)-\mathrm{H}(6)$ & 0.93 \\
\hline$C(10)-C(11)$ & $1.364(4)$ \\
\hline $\mathrm{C}(10)-\mathrm{H}(10)$ & 0.93 \\
\hline$C(11)-C(12)$ & $1.363(4)$ \\
\hline $\mathrm{C}(11)-\mathrm{H}(11)$ & 0.93 \\
\hline$C(2)-C(1)$ & $1.364(4)$ \\
\hline $\mathrm{C}(2)-\mathrm{H}(2)$ & 0.93 \\
\hline$C(1)-C(6)$ & $1.379(3)$ \\
\hline $\mathrm{C}(1)-\mathrm{H}(1)$ & 0.93 \\
\hline$C(13)-C(12)$ & $1.369(4)$ \\
\hline $\mathrm{C}(13)-\mathrm{H}(13)$ & 0.93 \\
\hline $\mathrm{C}(12)-\mathrm{H}(12)$ & 0.93 \\
\hline$C(14)-C(20)$ & $1.381(3)$ \\
\hline$C(14)-C(15)$ & $1.384(3)$ \\
\hline$C(15)-C(16)$ & $1.379(3)$ \\
\hline $\mathrm{C}(15)-\mathrm{H}(15)$ & 0.93 \\
\hline$C(16)-C(17)$ & $1.383(3)$ \\
\hline $\mathrm{C}(16)-\mathrm{H}(16)$ & 0.93 \\
\hline$C(17)-C(19)$ & $1.384(4)$ \\
\hline$C(17)-C(18)$ & $1.510(4)$ \\
\hline $\mathrm{C}(18)-\mathrm{H}(18 \mathrm{~A})$ & 0.96 \\
\hline $\mathrm{C}(18)-\mathrm{H}(18 \mathrm{~B})$ & 0.96 \\
\hline $\mathrm{C}(18)-\mathrm{H}(18 \mathrm{C})$ & 0.96 \\
\hline$C(20)-C(19)$ & $1.385(4)$ \\
\hline $\mathrm{C}(20)-\mathrm{H}(20)$ & 0.93 \\
\hline $\mathrm{C}(19)-\mathrm{H}(19)$ & 0.93 \\
\hline
\end{tabular}

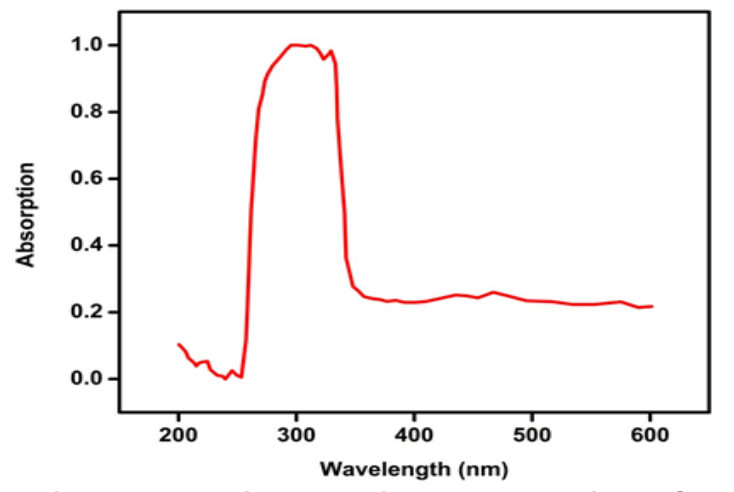

Fig. 5. Electronic absorption spectrum of PBITS

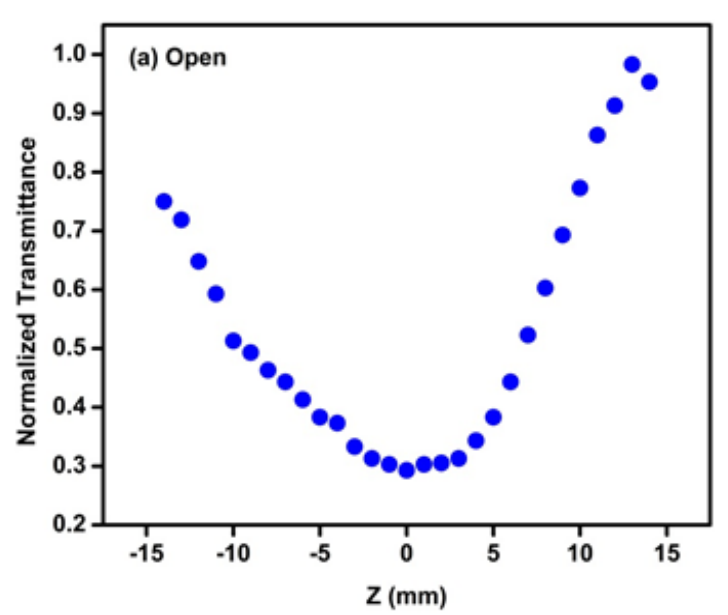

Fig. 6(a). Normalized transmittance with open aperture

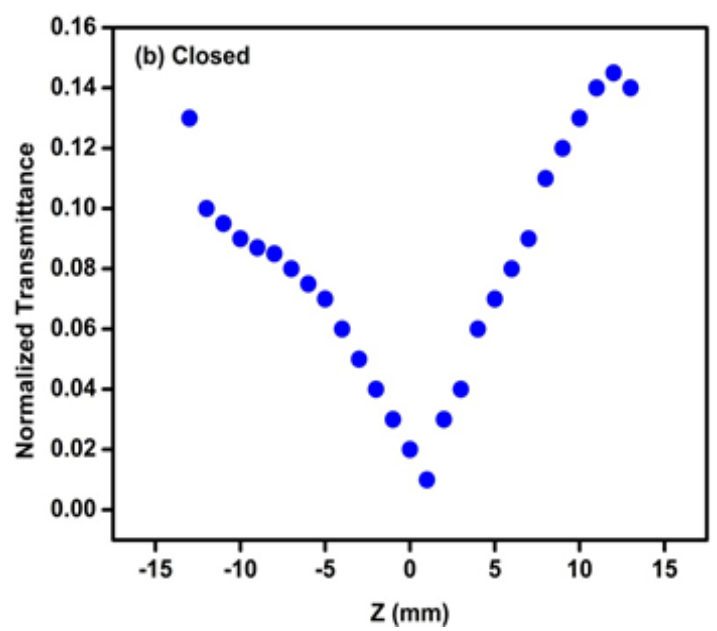

6(b) Normalized transmittance with closed aperture 
Table. 3: Bond angles [Å] forPBITS

\begin{tabular}{|c|c|}
\hline $\mathrm{O}(2)-\mathrm{S}(1)-\mathrm{O}(3)$ & $114.48(11)$ \\
\hline $\mathrm{O}(2)-\mathrm{S}(1)-\mathrm{O}(1)$ & $114.15(12)$ \\
\hline $\mathrm{O}(3)-\mathrm{S}(1)-\mathrm{O}(1)$ & $110.06(10)$ \\
\hline $\mathrm{O}(2)-\mathrm{S}(1)-\mathrm{C}(14)$ & $106.17(11)$ \\
\hline $\mathrm{O}(3)-\mathrm{S}(1)-\mathrm{C}(14)$ & $105.48(10$ \\
\hline $\mathrm{O}(1)-\mathrm{S}(1)-\mathrm{C}(14)$ & $105.63(9)$ \\
\hline$C(7)-N(1)-C(5)$ & $108.24(18$ \\
\hline $\mathrm{C}(7)-\mathrm{N}(1)-\mathrm{H}(1 \mathrm{~N} 1)$ & 125.9 \\
\hline $\mathrm{C}(5)-\mathrm{N}(1)-\mathrm{H}(1 \mathrm{~N} 1)$ & 125.9 \\
\hline$C(7)-N(2)-C(6)$ & $108.24(18$ \\
\hline $\mathrm{C}(7)-\mathrm{N}(2)-\mathrm{H}(2 \mathrm{~N} 2)$ & 125.9 \\
\hline $\mathrm{C}(6)-\mathrm{N}(2)-\mathrm{H}(2 \mathrm{~N} 2)$ & 125.9 \\
\hline$C(4)-C(3)-C(2)$ & $121.1(2)$ \\
\hline $\mathrm{C}(4)-\mathrm{C}(3)-\mathrm{H}(3)$ & 119.4 \\
\hline $\mathrm{C}(2)-\mathrm{C}(3)-\mathrm{H}(3)$ & 119.4 \\
\hline$C(5)-C(4)-C(3)$ & $115.9(2)$ \\
\hline $\mathrm{C}(5)-\mathrm{C}(4)-\mathrm{H}(4)$ & 122.1 \\
\hline $\mathrm{C}(3)-\mathrm{C}(4)-\mathrm{H}(4)$ & 122.1 \\
\hline$C(6)-C(5)-C(4)$ & $122.6(2)$ \\
\hline$C(6)-C(5)-N(1)$ & $106.4(2)$ \\
\hline$C(4)-C(5)-N(1)$ & $131.0(2)$ \\
\hline$N(1)-C(7)-N(2)$ & $110.2(2)$ \\
\hline$N(1)-C(7)-C(8)$ & 124.95(19) \\
\hline$N(2)-C(7)-C(8)$ & $124.81(19)$ \\
\hline$C(9)-C(8)-C(13)$ & $118.8(2)$ \\
\hline$C(9)-C(8)-C(7)$ & $120.9(2)$ \\
\hline$C(13)-C(8)-C(7)$ & $120.3(2)$ \\
\hline$C(10)-C(9)-C(8)$ & $119.9(2)$ \\
\hline$C(10)-C(9)-H(6)$ & 120.0 \\
\hline $\mathrm{C}(8)-\mathrm{C}(9)-\mathrm{H}(6)$ & 120.0 \\
\hline$C(11)-C(10)-C(9)$ & $120.7(2)$ \\
\hline $\mathrm{C}(11)-\mathrm{C}(10)-\mathrm{H}(10)$ & 119.6 \\
\hline$C(9)-C(10)-H(10)$ & 119.6 \\
\hline$C(12)-C(11)-C(10)$ & $120.0(2)$ \\
\hline$C(12)-C(11)-H(11)$ & 120.0 \\
\hline $\mathrm{C}(10)-\mathrm{C}(11)-\mathrm{H}(11)$ & 120.0 \\
\hline$C(1)-C(2)-C(3)$ & $122.1(3)$ \\
\hline $\mathrm{C}(1)-\mathrm{C}(2)-\mathrm{H}(2)$ & 119.0 \\
\hline $\mathrm{C}(3)-\mathrm{C}(2)-\mathrm{H}(2)$ & 119.0 \\
\hline$C(2)-C(1)-C(6)$ & $116.4(2)$ \\
\hline $\mathrm{C}(2)-\mathrm{C}(1)-\mathrm{H}(1)$ & 121.8 \\
\hline$C(6)-C(1)-H(1)$ & 121.8 \\
\hline$C(5)-C(6)-C(1)$ & $121.9(2)$ \\
\hline$C(5)-C(6)-N(2)$ & $106.9(2)$ \\
\hline$C(1)-C(6)-N(2)$ & $131.2(2)$ \\
\hline
\end{tabular}

$\begin{array}{lc}\mathrm{C}(12)-\mathrm{C}(13)-\mathrm{C}(8) & 119.5(2) \\ \mathrm{C}(12)-\mathrm{C}(13)-\mathrm{H}(13) & 120.3 \\ \mathrm{C}(8)-\mathrm{C}(13)-\mathrm{H}(13) & 120.3 \\ \mathrm{C}(11)-\mathrm{C}(12)-\mathrm{C}(13) & 11.1(2) \\ \mathrm{C}(11)-\mathrm{C}(12)-\mathrm{H}(12) & 119.4 \\ \mathrm{C}(13)-\mathrm{C}(12)-\mathrm{H}(12) & 119.4 \\ \mathrm{C}(20)-\mathrm{C}(14)-\mathrm{C}(15) & 119.2(2) \\ \mathrm{C}(20)-\mathrm{C}(14)-\mathrm{S}(1) & 120.99(17) \\ \mathrm{C}(15)-\mathrm{C}(14)-\mathrm{S}(1) & 119.78(16) \\ \mathrm{C}(16)-\mathrm{C}(15)-\mathrm{C}(14) & 120.4(2) \\ \mathrm{C}(16)-\mathrm{C}(15)-\mathrm{H}(15) & 119.8 \\ \mathrm{C}(14)-\mathrm{C}(15)-\mathrm{H}(15) & 119.8 \\ \mathrm{C}(15)-\mathrm{C}(16)-\mathrm{C}(17) & 121.0(2) \\ \mathrm{C}(15)-\mathrm{C}(16)-\mathrm{H}(16) & 119.5 \\ \mathrm{C}(17)-\mathrm{C}(16)-\mathrm{H}(16) & 119.5 \\ \mathrm{C}(16)-\mathrm{C}(17)-\mathrm{C}(19) & 118.2(2) \\ \mathrm{C}(16)-\mathrm{C}(17)-\mathrm{C}(18) & 120.5(2) \\ \mathrm{C}(19)-\mathrm{C}(17)-\mathrm{C}(18) & 121.3(2) \\ \mathrm{C}(17)-\mathrm{C}(18)-\mathrm{H}(18 \mathrm{~A}) & 109.5 \\ \mathrm{C}(17)-\mathrm{C}(18)-\mathrm{H}(18 \mathrm{~B}) & 109.5 \\ \mathrm{H}(18 \mathrm{~A})-\mathrm{C}(18)-\mathrm{H}(18 \mathrm{~B}) & 109.5 \\ \mathrm{C}(17)-\mathrm{C}(18)-\mathrm{H}(18 \mathrm{C}) & 109.5 \\ \mathrm{H}(18 \mathrm{~A})-\mathrm{C}(18)-\mathrm{H}(18 \mathrm{C}) & 109.5 \\ \mathrm{H}(18 \mathrm{~B})-\mathrm{C}(18)-\mathrm{H}(18 \mathrm{C}) & 109.5 \\ \mathrm{C}(14)-\mathrm{C}(20)-\mathrm{C}(19) & 119.9(2) \\ \mathrm{C}(14)-\mathrm{C}(20)-\mathrm{H}(20) & 120.1 \\ \mathrm{C}(19)-\mathrm{C}(20)-\mathrm{H}(20) & 120.1 \\ \mathrm{C}(17)-\mathrm{C}(19)-\mathrm{C}(20) & 121.3(2) \\ \mathrm{C}(17)-\mathrm{C}(19)-\mathrm{H}(19) & 119.3 \\ \mathrm{C}(20)-\mathrm{C}(19)-\mathrm{H}(19) & 119.3 \\ & \end{array}$

\section{Z-scan studies}

The Z-scan is a well-known experimental technique to measure the intensity dependent third order nonlinear susceptibility of the materials ${ }^{13,14}$. The open and closed aperture Z-scan configurations are used to investigate the nonlinear absorption coefficient $\beta$ and nonlinear refractive index $n_{2}$. Fig 6a shows the normalized transmittance ( $T$ ) with a closed aperture as a function of the distance $z$ along the lens axis in the far field. The Fig. 6(b) shows the normalized transmittance with open aperture as a function of the distance $z$ along the lens axis in the far field. The nonlinear refractive index $\left(n_{2}\right)$ of the crystal was calculated using the standard relations given below:

$\Delta \phi_{0}=\frac{\Delta T_{p-v}}{0.406(1-s)^{0.25}}$ 
where $\Delta T_{p-v}$ is the difference between the normalized peak and valley transmittance and $S$ is the linear transmittance of the aperture. The nonlinear refractive index $\left(n_{2}\right)$ and nonlinear absorption coefficient $(\beta)$ are given by,

$n_{2}=\frac{\Delta \Phi}{k I_{0} L_{e f f}}$

$\beta=\frac{2 \sqrt{2} \Delta T}{I_{0} L_{e f f}}$

where $k$ is the wave number $k=2 p / \lambda$ and

$L_{e f f}=\frac{1-e^{(-\alpha L)}}{\alpha}$

with $I_{o}=\frac{P}{\pi \omega_{0}^{2}}$ defined as the peak intensity within the sample, where $L_{e f f}$ is the thickness of the sample and $\alpha$ is the linear absorption coefficient. The real and imaginary parts of the third order nonlinear susceptibility $\chi(3)$ are defined as

$$
\operatorname{Re} \chi^{(3)}=10^{-4} \frac{\left({ }_{o} C^{2} n_{o}^{2} n^{2}\right)}{\pi}(e s u)
$$

$\operatorname{Im} \chi^{(3)}=10^{-2} \frac{\left(_{o} C^{2} n_{o}^{2} \lambda \beta\right)}{4 \pi^{2}}(e s u$

where $\varepsilon_{0}$ is the vacuum permittivity, $\mathrm{n}_{0}$ is the linear refractive index of the sample and $c$ is the velocity of light in vacuum. Thus, we can easily obtain the absolute value of $\chi(3)$ using the following formula

$$
\left|\chi^{(3)}\right|=\left[\left(\operatorname{Re} \chi^{(3)}\right)^{2}+\left(\operatorname{Im} \chi^{(3)}\right)^{2}\right]^{\frac{1}{2}}
$$

As seen from the closed aperture $Z$ scan curve, the prefocal transmittance valley is followed by the post focal peak, which is the positive nonlinearity ${ }^{15}$. The calculated value of the nonlinear refractive index $\left(n_{2}\right)$ is $6.4014910^{-8} \mathrm{~cm}^{2} / \mathrm{W}$. The value of the nonlinear absorption coefficient $(\beta)$ estimated from the open aperture Z-scan curve is $2.4603 \mathrm{x}$ $10^{-4} \mathrm{~cm} / \mathrm{W}$. The third order susceptibility of PBITS is $1.3061 \times 10^{-7}$ esu. As the material has a positive refractive index, it results in self-focusing nature of the material, which is an essential property for all optical switching devices ${ }^{16}$.

\begin{tabular}{|c|c|c|c|c|c|}
\hline $\mathrm{D}-\mathrm{H} \ldots \mathrm{A}$ & $d(D-H)$ & $d(H . . A)$ & $<\mathrm{DHA}$ & $d(D . . A)$ & Symmetry \\
\hline $\mathrm{N} 1-\mathrm{H} 1 \mathrm{~N} 1 \ldots \mathrm{O} 1$ & 0.860 & 1.82 & 170 & 2.674 & $x, y, z+1$ \\
\hline $\mathrm{N} 2-\mathrm{H} 2 \mathrm{~N} 2 \ldots \mathrm{O} 3$ & 0.860 & 1.87 & 160 & 2.691 & $x,-1+y, 1+z$ \\
\hline $\mathrm{C} 9-\mathrm{H} 6 \ldots \mathrm{O} 1$ & 0.930 & 2.56 & 160 & 3.450 & $x, y, 1+z$ \\
\hline $\mathrm{C} 16-\mathrm{H} 16 \ldots \mathrm{O} 2$ & 0.930 & 2.54 & 156 & 3.410 & $-1+x, y, z$ \\
\hline C2O-H2O...O2 & 0.930 & 2.51 & 105 & 2.892 & \\
\hline
\end{tabular}

Table. 4: Hydrogen bonds for PBITS

\section{CONCLUSIONS}

New bright, transparent organic compound, PBITS was synthesized and crystal crown by slow evaporation solution growth method at room temperature. The material synthesized characterized by various analytical, spectroscopic and single crystal XRD studies. From $\mathrm{X}$-ray diffraction studies, PBITS single crystal is observed that the crystal belongs to the triclinic system with the space group of P-1. UV-Visible absorption spectrum confirms the suitability of the title crystal for various optical applications. The molecular structure of the compound was confirmed by the FTIR, ${ }^{1} \mathrm{H}$ and ${ }^{13} \mathrm{C}$ NMR spectral studies.Z-scan studies reveal the self-focusing nature of the material, which is a vital property for all optical switching and optical limiting applications.

\section{REFERENCES}

1. Babu, B.;Chandrasekaran, J.;Thirumurugan, R.;Jayaramakrishnan, V.;Anitha,K.;J. Mater. Sci: Mater. Electron., 2017, 28, 1124.

2. Majchrowski, A.;Kityk, I.V.;£ukasiewicz,
T.;Mefleh, A.; Benet, S.;Opt. Mater., 2000, 15, 51.

3. Subhashini,V:; Ponnusamy,S; Muthamizhchelvan, C.; Spectrochim. Acta Part A., 2012, 87, 265. 4. Saravana Kumar, G.;Murugakoothan, 
P.;Optik., 2015, 126,68.

5. MartinBrittoDhas, S.A.;Natarajan,S.;Opt. Commun., 2008, 281, 457.

6. Peramaiyan, G.;Pandi, P.;Sornamurthy, B.M.;Bhagavannarayana, G.;Mohan Kumar, R.;Spectrochim. Acta Part A., 2012, 95, 310.

7. Thirupugalmani, K.; Karthick, S.; Shanmugam, G.; Kannan, V.; Sridhar, B.;Nehru, K.; Brahadeeswaran, S.; Opt. Mater. 2015., 49, 158.

8. Chemla, D.S.;Zyss, J.;Nonlinear Optical Properties of Organic molecules and crystals, 1-2, Academic Press, Orlando, New York, 1987.

9. Suresh, M.; Asath Bahadur S.; and Athimoolam, S. J.; J. Mol. Struct. 2016., 1112, 63.
10. Mohana, J.;Ahila, G.;DivyaBharathi, M.; Anbalagan, G.;J. Cryst. Growth., 2016, 450, 181.

11. Sheldrick, G.M.;SHELXL97 and SHELXS97, University of Gottingen, Germany., 1997, 327.

12. Babu,B.; Chandrasekaran, J.; Balaprabhakaran, S.;Optik., 2014, 125,3005.

13. Sheik-Bahae, M.;Said, A.A.;Van Stryland E.W.;Opt. Lett.,1989, 17, 955.

14. Sheik-Bahae, M.;Said, A.A.;Wei, T.H.;Hagan, D.J.;Van Stryland,E.W.; IEEE J. Quan. Elect.,1990, 26, 760.

15. Gomez, S.L.;Cuppo, F.L.S.;FigueriredoNeto, A.M.;Braz. J. Phys.,2003, 33, 813.

16. Sheik, M. David, C.H.; Hagan, D.J.; Van Stryland, E.W.;IEEEJ. Quan. Elect., 1991, 27, 1296. 